\title{
The Impact of Interactionist Dynamic Assessment on Explanation Writing Ability of Intermediate EFL Learners
}

\author{
Hooshang Khoshsima, Amin Saed, Mohammad Mortazavi* \\ English Language Department, Chabahar Maritime University, Chabahar, Iran \\ E-mail Address: \\ mortazavi100@yahoo.com (M. Mortazavi) \\ ${ }^{*}$ Corresponding author
}

To cite this article:

Hooshang Khoshsima, Amin Saed, Mohammad Mortazavi. The Impact of Interactionist Dynamic Assessment on Explanation Writing Ability of Intermediate EFL Learners. International Journal of Language and Linguistics. Vol. 4, No. 5, 2016, pp. 183-189. doi: $10.11648 /$ j.ij1l.20160405.13

Received: September 8, 2016; Accepted: September 21, 2016; Published: October 10, 2016

\begin{abstract}
Dynamic assessment is an approach based on sociocultural theory of mind aimed to combine instruction and assessment in which learners' development is simultaneously assessed and improved with regard to their Zone of Proximal Development. This study aimed to integrate principles of dynamic assessment in providing feedback with process-genre approach to teach explanation genre writing. The participants of the study $(\mathrm{N}=10)$ were male and female students majoring English translation for BA degree at Chabahar Maritime University. The results of independent samples $t$-test showed that the learners who were exposed to interactionist approach of DA, performed better than the control group in posttest. Findings of the study suggested that providing feedback through negotiation let students understand their problem and remove them better.
\end{abstract}

Keywords: Assessment for Learning, Formative Assessment, Dynamic Assessment, ZPD, Explanation Genre

\section{Introduction}

Writing is undeniably important for students in an academic context and it becomes more as far as learners of other languages are of concern. Writing, especially academic writing, could be considered more difficult than other skills since, on the one hand writers have to think, generate and organize different ideas and on the other hand, they have to translate their ideas into a readable text that suits the context better (Richards \& Renandya, 2002). Writing can be seen as a tool for the accomplishment of other purposes like taking notes or as an end which its main aim is transferring ideas and messages (Ur, 2009). To this end, a well written text should be concise, clear, readable, finding the right tone, consistent and relevant (Ellis, 2009). Besides, writing is an activity which is socially and culturally affected and is used to reach a social or individual purpose (Sperling, 1996). So, texts are becoming more context and socially specific and needed to be more purposeful. As Johns (2002) describes in the introduction of her book, in the realm of language teaching, it has been more than thirty years that the focus has shifted to the situations and contexts in which writing is taking place. So the idea of writing genres comes to the surface over time. One of the most well-known definitions of genre proposed by Swales (1990) in that a genre is '.... class of communicative events, the members of which share some set of communicative purposes. These purposes are recognized by the expert members of the parent discourse community, and thereby constitute the rationale for the genre. This rationale shapes the schematic structure of the discourse and influences and constrains choice of content and style. Communicative purpose is both a privileged criterion and one which operates to keep the scope of a genre as here conceived narrowly focused on comparable rhetorical action' (p. 59). Similarly, Halliday (1973; cited in Kumaravadivelu, 2008, p. 8) defined language as meaning potential, that is, a collection of meanings in different social contexts that speaker and hearer choose the appropriate ones. In the same vein, Hyland (2003) explains that writer's choices are integrally related to context and are affected by different social activities exist between reader and writer and also by what inhibits or facilitates this interaction, if we look at writing from a social perspective (p. 21). The point that is conspicuously clear is that varying genres have different features. Despite the amount of conducted researches 
concerned about teaching genres, there still exists a problem related to teaching/learning process. Teachers need to make sure that their students truly mastered a specific genre's features and how further he/she has moved toward the prespecified goals of learning.

The present paper is a report on a study that implemented an innovative way of assessing academic writing for learning in an attempt to support learners. This method is called dynamic assessment (hereafter DA) which is 'an approach to understanding and conceiving an individual in the assessment process' (Murphy, 2011, p. 1). The main focus of the DA is to assess and promote learner's abilities at the same time (Shrestha \& Coffin, 2011). This promotion of learner's abilities not only help learners to get through a specific task, but also to help them deal with future tasks through mediation that took place between the learner and instructor (Poehner \& Lantolf, 2005). In this paper we are mainly concerned with the final performance of the learners who exposed to DA, while they were taught writing genres.

\subsection{Formative Writing Assessment}

This study concentrated on formative assessment of writing which is focused on promotion of learning. Formative assessment is usually continuous and ongoing which centers on learning and advancement in writing (Huot, 2002). It can be considered as a learning process in which student and teacher work together continuously in order to improve learner's achievement (Moss \& Brookhart, 2009). In other words, a kind of assessment can be called formative which takes place during the instruction, helps learner to gain instruction goals and find out if students understanding had any progress (Furtak \& Ruiz-Primo, 2008). (Taras, 2005) believes that formative assessment must include feedback that makes it clear there is a gap between actual level and the level learner must achieve and also show how the learner can improve himself to the ideal level. In this regard, (Looney, 2005) defined formative as a sort of interactive continuous assessment of student's progress and understanding for finding learner's need and adjust teaching accordingly. As a result of formative assessment, students understand and use learning targets to set their goals, choose proper strategies and assess their learning process as they move toward their goals. The more they work the more competent, motivated and persistent they become to set their own goals and regulate their effort. Scholars in the field of assessment agree that although used with different methods, formative assessment supports learning.

Although one of the key factors in students' success in academic context is writing, especially in EFL contexts, writing assessment does not really seem to be integrated with learning. Accordingly, the main focus of assessment seemed to be task variables, inter-rater reliability and rating scales in standardized tests rather than investigate the link between writing assessment and learners' writing development (Huot, 2002). Despite the credit given to formative assessment (e.g. Carless, 2006; Walker, 2009; Weaver, 2006), writing assessment for student's learning in EFL context is under-researched.
Formative feedback which is a response that student is provided with regarding his performance during the assessment is closely related to our study. Feedback is information about the gap that exists between current level and intended level within a system which is used to change the gap in some way (Ramaprasad, 1983). Two points about the feedback system are important: first it is not helpful to tell the student there is an error but, the teacher should tell him what kind of error he made and how to fix it and second, information generated in a feedback system affect the future performance of the system (Wiliam, 2011). According to (Nicol \& Macfarlane-Dick, 2006), good feedback has the following characteristics: 'it (1) specifies good performance; (2) facilitates self-assessment; (3) provides students with information about their learning; (4) motivate teacher and students to have communication; (5) enhances motivation and self-esteem; (6) creates opportunities to narrow down the gap between current and intended performance; and (7) enables teachers to change their teaching' (as cited in Lee, 2007, p. 182).

Different studies investigated learner perceptions about feedback they received from instructor (e.g. Carless, 2006; Ellery, 2008; Handley \& Williams, 2009; Walker, 2009; Weaver, 2006). However, without analyzing subsequent performance, it's nearly impossible to know how much of those feedbacks were applied by the students. On the other hand, Stern \& Solomon (2006) found that tutor comments were mostly focused on aspects like grammar or spelling. Walker (2009) also found that teacher's feedback was not so helpful for the students.

It can be concluded then, that not all kinds of formative feedback can be helpful because some of them lack solid framework. One other possible reason could be individual differences that must seriously be taken into account while providing feedback. Accordingly this study tries to make a contribution to this area of research by investigating the effects of providing developmental feedback within the framework of DA in the context of academic writing.

\subsection{Dynamic Assessment}

In contrast and in response to traditional psychometric assessment in which students' performance was measured statistically, researchers tried to find a way to consider psychological and cognitive aspects in their assessment as well. Dynamic assessment is such an approach that came out of the work of Russian psychologist L. S. Vygotsky. DA is based on sociocultural theory of mind proposed by Vygotsky (1987) in which human cognition and consequently learning is not bounded to individual's biology but is considered as social and/or cultural enterprise. Central to DA is the notion of Zone of Proximal Development (ZPD) and mediation. Vygotsky (1978) defined ZPD as '...the distance between the actual developmental level as determined through independent problem solving and the level of potential development as determined through problem solving under adult guidance or in collaboration with more capable peers' (p. 86). He believed that working within the learner's ZPD 
helps us explore both the previously matured functions which are products of past development and the mental functions that have not yet fully developed. So DA considers assessment as a process rather than a product. Mediation is another component of DA. It helps instructor to deal with how learner's potential abilities becomes his actual ones. Vygotsky believed that human beings are related to their world both physically and psychologically, so they have to mediate their relation in concrete ways through use of physical tools and in abstract ways by using symbolic tools (Poehner, 2008). Cultural artifacts that are called by Vygotsky as symbolic tools in contrast to physical tools, could be signs, various numeric and writing systems, graphs, charts and tables (Kozulin, 2003). In this study, mediation refers to reciprocal and intentional interaction between tutor and learner regarding learner's problems and with the consideration of their ZPD. Using mediation, tutor can find the learner's actual and potential level of abilities and provide sort of feedback that help him move to next levels.

To date, DA studies have been conducted in EFL contexts with writing ability as the main concern. However, nearly all of them worked on general writing ability. Isavi (2012) applied the regulatory scale proposed by Aljaafreh and Lantolf (1994) to assess learners writing ability, specifically tenses and articles. He used an interventionist approach which ultimately resulted in writing improvement. Ghahremani and Azarizad (2013) also investigated the effects of dynamic assessment on EFL process writing and their main focus were content and organization. Again it'd been proved that teacher's mediation was really effective for the learners both quantitatively and qualitatively. Students' writings had improved in case of content, organization, length and macro-revision imposed on the drafts. Alavi and Taghizadeh (2014) conducted another study with the purpose of investigation of the impact DA has on the L2 learners' internalization of writing content and organization skills and strategies and they found that students performed better in post-tests than pre-test. Aghaebrahimian et. al. (2014) investigated how effective is the use of DA compared to TA in final evaluation of the process and product of learners. After the eight weeks of instruction, results showed that experimental group performed better than control group.

A review of studies done related to dynamic assessment and writing ability reveals that, nearly most of them were sentence based. It means, as Luu (2011) says they 'focus on sentence writing for sentence building tests, rather than focusing on creating compositions to serve the purpose of plurality of real readers outside the classroom context' ( $p$. 122). On the other hand, there are studies like Lingzhu (2009), Chaisiri (2010), Afful (2009), Malakul and Bowering (2006) that focused on genres and sub-genres without regard to DA. Accordingly, the researcher in this paper decided to combine dynamic assessment with teaching genre writing.

\section{The Study}

The study reported here is substantially quantitative although takes the benefit of DA's inherent alignment with a genetic method which examines the qualitative development of individuals higher mental functions over time (Lantolf and Thorne, 2006). In this section we are going to represent the methodology and procedure deployed to get the impact of applying DA principles within the framework of processgenre based approach to teach writing on the genre writing ability of EFL learners. Having this in mind, the following research question and hypothesis was proposed:

Q. Is there any significant difference between the amount of improvement in explanation writing ability of Iranian intermediate EFL learners achieved through process-genre approach with DA and process-genre approach without DA?

H0. There is no significant difference between the amount of improvement in explanation writing ability of Iranian intermediate EFL learners achieved through process-genre approach with DA and process-genre approach without DA.

\subsection{Participants and Context}

The subjects of this study were 10 students, both male and female, with the same level of proficiency majoring English translation at Chabahar Maritime University (CMU); all of which had the same amount of exposure to English language courses and also have passed the writing course. All the participants were learning English as L2 language and were native speakers of Persian. Their ages mainly ranged from 19 to 24 and both male and female students were participated in this study. The subjects were assigned into two groups: control and interactionist group; each of which had 5 member. Both groups received the same amount of instruction which means one sessions every week, each session lasted 1 and a half hour (whole class time) for 6 sessions.

\subsection{Procedure}

After the selection of students which were 15 students of Chabahar Maritime University of Iran majoring English translation, a TOEFL (PBT) general proficiency test was administered to all of them to make sure they are at the same intended level of language proficiency which was Intermediate level. Then, the students were given a writing test in which they had to write an explanatory paragraph. All the paragraphs were rated by three independent raters and two of them, highly correlated ones, selected in order to reach the final score for each student.

Confirming the homogeneity of students before the instruction, ten students were selected and randomly assigned to two groups, one control and the other interactionist group. It should be noted that the homogeneity test was also considered as pre-test of the instruction. The instruction consisted of 6 sessions for both groups which was divided to two parts. As it was the first time that participants were facing different genres of writing, there had to be presentation and some practice about explanation genre before they begin to write. So a process-genre based approach was adopted to teach students explanation genre. This approach which was proposed by Badger and White 
(2000), is the best approach at hand for now since it consisted of both process-based approach features to teach learners how to write and genre-based approach to let them take social and cultural aspects of genres into consideration as well. Based on the model proposed by Yan (2005), writing within this approach can have six steps: preparation, modeling and reinforcing, planning, joint construction, independent construction and revising.

\section{Presentation and Practice}

For the first three sessions of instruction all the students in both groups were presented with explanatory writing and its specific features as the first two steps of this model. The first thing that was explained to the students was the main purpose that we write, which is typically conveying a message or idea, etc. and that in different genres this purpose would be accomplished differently. Then the main purpose of explanation and consequently the specific features of that was explained. Then they had to practice whatever had been presented to them, first by recognition and then application. So, participants were given different paragraphs and they had find explanation specific features and finally, they were given paragraphs and had to rewrite those paragraphs while they were applying explanation feature to those paragraphs.

\section{Writing Sessions}

From the fourth session control and experimental group were treated differently. Participants in control group were prepared with a topic each session. There was warm up in either forms of reading or free discussion about each topic (planning stage). Then, students began to write their paragraph with the help of the teacher. Any sort of help, feedback or error correction in control group was direct and without any consultation, which is what regularly happens in writing classes.

Participants in experimental group went through the same procedure, with the difference that they were not given feedback or error correction directly. But based on interactionist approach of DA, as Poehner (2008) indicated, any necessary help or feedback emerged from the interaction between instructor and learner from implicit to explicit which was highly sensitive to learner's ZPD. In this model traditional examinee-examiner relationship are abandoned in favor of a teacher-student relationship (Kozulin, 2002). So during the writing sessions students could freely talk to the teacher and the teacher, having in mind to provide students with feedback according to their ZPD, helped learners to alleviate their problems.

\subsection{Data Collection}

When instruction sessions finished, students were given another paragraph writing test as the post-test in that they had to write an explanatory paragraph. These paragraphs where given to the same three raters who were hired for the pre-test. The two highly correlated raters had been selected and the mean of their scores was considered as the final score of the students for the post-test. Results of pre- and post-test where compared in order to reach a confirmation that whether applying interactionist approach of dynamic assessment principles had any effect on promotion of explanatory writing ability of Iranian intermediate EFL learners.

\subsection{Data Analysis and Discussion}

This study dealt with the possible effects, the result of which is possible difference between the amounts of improvement achieved through DA and non-DA approaches in genre writing ability. As it was stated, at the beginning of this study, a paragraph writing test before the instruction was administered for the sake of both determining homogeneity of the students and their pre-test for the final analysis. Tables 1 and 2 show the results of pre-test of control and experimental groups.

Table 1. Descriptive statistics for the results of writing proficiency pre-test of interactionist and control groups.

\begin{tabular}{llllll}
\hline \multicolumn{6}{l}{ Group Statistics } \\
\hline & Groups & N & Mean & Std. Deviation & Std. Error Mean \\
\hline Writing & 1 & 5 & 4.3000 & 1.75357 & .78422 \\
Proficiency & 3 & 5 & 3.8000 & 1.09545 & .48990 \\
\hline
\end{tabular}

The computed writing proficiency mean and standard deviation of the participants in interactionist group amounted to 4.30 and 1.75 ; and the evaluated writing proficiency mean and standard deviation of participants in control group equaled to 3.80 and 1.09 , respectively. An inspection of the mean scores showed that there was a little difference between the treatment and control group in terms of overall proficiency in writing explanation genre.

Table 2. Independent-samples t-test for the result of writing proficiency pre-test of interactionist and control groups.

\begin{tabular}{|c|c|c|c|c|c|c|c|c|c|c|}
\hline \multicolumn{11}{|c|}{ Independent Samples Test } \\
\hline & & \multicolumn{2}{|c|}{$\begin{array}{l}\text { Levene's Test for } \\
\text { Equality of Variances }\end{array}$} & \multicolumn{7}{|c|}{ t-test for Equality of Means } \\
\hline & & \multirow[t]{2}{*}{$\mathbf{F}$} & \multirow[t]{2}{*}{ Sig. } & \multirow[t]{2}{*}{$\mathbf{t}$} & \multirow[t]{2}{*}{ df } & \multirow[t]{2}{*}{ Sig. (2-tailed) } & \multirow[t]{2}{*}{ Mean Difference } & \multirow{2}{*}{$\begin{array}{l}\text { Std. Error } \\
\text { Difference }\end{array}$} & \multicolumn{2}{|c|}{$\begin{array}{l}95 \% \text { Confidence Interval of } \\
\text { the Difference }\end{array}$} \\
\hline & & & & & & & & & Lower & Upper \\
\hline Writing & $\begin{array}{l}\text { Equal variances } \\
\text { assumed }\end{array}$ & .986 & .350 & .541 & 8 & .603 & .50000 & .92466 & -1.63227 & 2.63227 \\
\hline
\end{tabular}

However, the independent sample $t$-test analysis showed that this difference was not statistically significant. The $\mathrm{P}$ value equals to $0.35(\mathrm{P}>0.05)$. Therefore, it can be said that there was not statistically significant difference between interactionist and control group on pre-test in overall proficiency in writing explanation genre. 
After the instruction another writing test was administered to determine the possible differences between interactionist and control group. Tables 3 and 4 display the results of posttest for control and experimental group.

Table 3. Descriptive statistics for the results of writing proficiency post-test of interactionist and control groups.

\begin{tabular}{llllll}
\hline Group Statistics & & & & & \\
\hline & Groups & N & Mean & $\begin{array}{l}\text { Std. } \\
\text { Deviation }\end{array}$ & $\begin{array}{l}\text { Std. Error } \\
\text { Mean }\end{array}$ \\
\hline Explanation post-test & 1 & 5 & 6.6000 & 1.38744 & .62048 \\
& 3 & 5 & 4.6000 & 1.14018 & .50990 \\
\hline
\end{tabular}

The computed writing proficiency mean and standard deviation of the participants in interactionist group amounted to 6.60 and 1.38; and the evaluated writing proficiency mean and standard deviation of participants in control group equaled to 4.60 and 1.14 , respectively. An inspection of the mean scores showed that there was a considerable difference between the treatment and control group in terms of overall proficiency in writing explanation genre.

Moreover, the independent sample $t$-test analysis showed that this difference was statistically significant because the $\mathrm{P}$ value equals to $0.03(\mathrm{P}<0.05)$. Therefore, it can be said that there was statistically significant difference between interactionist and control group on the post-test in overall proficiency in writing explanation genre in favor of experimental group.

Table 4. Independent-samples t-test for the result of writing proficiency post-test of interactionist and control groups.

\begin{tabular}{|c|c|c|c|c|c|c|c|c|c|c|}
\hline \multicolumn{11}{|c|}{ Independent Samples Test } \\
\hline & & \multicolumn{2}{|c|}{$\begin{array}{l}\text { Levene's Test for } \\
\text { Equality of Variances }\end{array}$} & \multicolumn{7}{|c|}{ t-test for Equality of Means } \\
\hline & & \multirow[t]{2}{*}{$\mathbf{F}$} & \multirow[t]{2}{*}{ Sig. } & \multirow[t]{2}{*}{$\mathbf{t}$} & \multirow[t]{2}{*}{ df } & \multirow[t]{2}{*}{ Sig. (2-tailed) } & \multirow{2}{*}{$\begin{array}{l}\text { Mean } \\
\text { Difference }\end{array}$} & \multirow{2}{*}{$\begin{array}{l}\text { Std. Error } \\
\text { Difference }\end{array}$} & \multicolumn{2}{|c|}{$\begin{array}{l}95 \% \text { Confidence Interval } \\
\text { of the Difference }\end{array}$} \\
\hline & & & & & & & & & Lower & Upper \\
\hline \multirow{2}{*}{$\begin{array}{l}\text { Explanation } \\
\text { post-test }\end{array}$} & $\begin{array}{l}\text { Equal variances } \\
\text { assumed }\end{array}$ & .334 & .579 & 2.490 & 8 & .038 & 2.00000 & .80312 & .14800 & 3.85200 \\
\hline & $\begin{array}{l}\text { Equal variances } \\
\text { not assumed }\end{array}$ & & & 2.490 & 7.710 & .039 & 2.00000 & .80312 & .13583 & 3.86417 \\
\hline
\end{tabular}

This study was designed not only to assess students writing and giving feedback, but also to promote improvement of their writing ability. The results of the research revealed a significant difference between dynamic and non-dynamic assessment with a statistically significant increase in the writing scores of the group being assessed dynamically. Although we did not dealt with the results qualitatively in this study but the results are in line with the findings of Shrestha and Coffin (2012). Using DA principles to provide students with proper feedback, helped both teacher and students find the problems and solve them better. Although they didn't used face-to-face interaction during their study, which we did, but they combined interaction with a scale of feedback provided by Aljaafreh and Lantolf (1994) and refer it as a text mediation.

The results are similar to a study conducted by Miao and Lv (2013) in china in terms of accuracy, complexity, fluency, local coherence and global coherence while the researchers used interactionist approach of DA. Their final results showed that the treatment group performed better than the control group. Their results also showed that the way feedback is provided in interactionist approach, avoids learners lucky guesses when they try to correct themselves, so their improvement would be more than those treated traditionally. One point to be kept in mind is that both in Miao and Lv (2013) and the present study, all the participants whether in control or experimental group had improvement but the amount of improvement in similar conditions is more important.

The findings of this study also support Hashemnezhad and Fatollahzadeh (2015) idea that using dynamic assessment can improve writing ability of students. The results of their study proved that dynamic assessment oriented instruction significantly improved the learning of L2 writing.

Xiaoxiao and Yan (2010) conducted a study which was designed to test the effect of using Dynamic Assessment framework on students' writing ability and motivation. He chose interactionist approach of dynamic assessment and the findings confirm the realization of the central objectives: 1) Learners' writing ability can be substantially and comprehensively improved; 2) Learners' motivation of writing can be markedly stimulated.

\section{Conclusion and Implications}

The main focus of DA is that instruction and assessment cannot be separated. The present study demonstrated that DA significantly promote learners' performance in genre writing ability. All the participants in experimental group performed better than those in control group. They also believed that learning using DA in their writing sessions help them understand what they are going to do when they want to write within a specific genre parameters. They rightly stated that through negotiation and reinforcement, learning experience was more pleasant and stress free and provided them with exactly what they needed to move forward and therefore it was more challenging for them.

The results of this study are tangible and there are practical implications for material developers and syllabus designers. There are few language materials (if any) which are designed based on the notion of DA and continuous assessment. Although there are some materials that incorporate portfolios or some other continuous means of assessment, the nature of such materials is still based on TA. In other word they only change the process of assessment from one-shot to 
continuous without paying attention to the relation between examiner and learner and to the dynamic nature of test administration or even to the notion of feedback. In designing a dynamic syllabus or material all these notions should be considered to produce materials that conduct their evaluation process dynamically, provide the learners with suitable and leveled-feedback in the process of evaluation and interactively engage the learners and instructor in the process of learning and evaluation.

\section{References}

[1] Afful, J. B. (2009). RHETORICAL ANALYSIS OF INTRODUCTIONS IN AN UNDERGRADUATE ENGLISH STUDIES COURSE. ESP World, www.esp-world.info, Issue 5 (26), Volume 8.

[2] Aghaebrahimian, A., Rahimirad, M., Ahmadi, A., \& Khalilpour Alamdari, J. (2014). Dynamic Assessment of Writing Skill in Advanced EFL Iranian Learners. Social and Behavioral Sciences 98, 60-67.

[3] Alavi, S., \& Taghizadeh, M. (2014). Dynamic Assessment of Writing: The Impact of Implicit/Explicit Mediations on L2 Learners' Internalization of Writing Skills and Strategies. Educational Assessment, 19, 1-16.

[4] Aljaafreh, A., \& Lantolf, L. P. (1994). Negative Feedback as Regulation and Second Language Learning in the Zone of Proximal Development. The Modern Language Journal, 78, iv, 465-483.

[5] Badger, R., \& White, G. (2000). A process genre approach to teaching writing. ELT Journal Volume 54 (2), 153-160.

[6] Carless, D. (2006). Differing perceptions in the feedback process. Studies in Higher Education, 31 (2), 219-233.

[7] Chaisiri, T. (2010). Implementing a Genre Pedagogy to the Teaching of Writing in a University Context in Thailand. Language Education in Asia, 1 (1), 181-199.

[8] Cole, M., John-Steiner, V., Scribner, S., \& Souberman, E. (1978). Mind in Society, The Development of Higher Psychological Processes. London: Harvard University Press.

[9] Ellery, K. (2008). Assessment for learning: A case study using feedback effectively in an essay-style test. Assessment and Evaluation in Higher Education, 33 (4), 421-429.

[10] Ellis, R. (2009). Communication Skills Stepladders to Success for the Professional. Bristol: Intellect Ltd.

[11] Furtak, E. M., \& Ruiz-Primo, M. A. (2008, February 29). Making Students' Thinking Explicit in Writing and Discussion: An Analysis of Formative Assessment Prompts. Science Education, 799-824.

[12] Ghahremani, D., \& Azarizad, R. (2013). The Effect of Dynamic Assessment on EFL Process Writing: Content and Organization. International Research Journal of Applied and Basic Sciences, Vol. 4 (4), 874-878.

[13] Handley, K., \& Williams, L. (2009). From copying to learning: Using exemplars to engage students with assessment criteria and feedback. Assessment and Evaluation in Higher Education.
[14] Hashemnezhad, H., \& Faollahzadeh, F. (2015). The Immediate and Delayed Effect of Dynamic Assessment on the Improvementof Iranian EFL Learners' Writing Performance. International Journal of Language Learning and Applied Linguistics World, 193-209.

[15] Huot, B. (2002). (Re)Articulating writing assessment: Assessment for teaching and learning. Utah: Utah State University Press.

[16] Hyland, K. (2003). Second Language Writing. New York: Cambridge University Press.

[17] Isavi, E. (2012). The Effect of Dynamic Assessment on Iranian L2 Writing Performance. Retrieved from http://eric.ed.gov/?id=ED530902.

[18] Johns, A. M. (2002). Genre in the Classroom, Multiple Perspective. Mahwah: Lawrence Erlbaum Associates, In.

[19] Kozulin, A., \& Grab, E. (2002). Dynamic Assessment of EFL Text Comprehension. SCHOOL PSYCHOLOGY INTERNATIONAL. Retrieved from http://www.researchgate.net/publication/247718407.

[20] Kozulin, A., Gindis, B., Ageyev, V. S., \& Miller, S. M. (2003). Vygotsky's Educational Theory in Cultural Context. Cambridge: Cambridge University Press.

[21] Kumaravadivelu, B. (2008). Understanding Language Teaching. Mahwah: Lawrence Erlbaum Associates, Inc.

[22] Lantolf, J. P., \& Thorne, S. L. (2006). Sociocultural theory and the genesis of second language development. Oxford: Oxford University Press.

[23] Lee, I. (2007). Feedback in Hong Kong Secondary Writing Classrooms: Assessment for Learning or Assessment of Learning? Assessing Writing, 180-198.

[24] Lingzhu, J. (2009). Genre-based Approach for Teaching English Factual Writing. Major Articles, Year 11; Issue 2. Retrieved from www.hltmag.co.uk/apr09/mart02.htm.

[25] Looney, J. (2005). Formative Assessment: Improving Learning in Secondary Classrooms. paris: Organization for Economic Cooperation and Development.

[26] Luu, T. T. (2011). Teaching Writing Through Genre-based Approach. BELT Journal, Porto Alegre, V. 2, N. 1, 121-136.

[27] Malakul, K., \& Bowering, M. (2006). The application of Genre Theory to improve Academic English Writing Courses. (pp. 328-334). Edith Cowan University, Perth Western Australia: Proceedings of the EDU-COM 2006 International Conference.

[28] MIAO, T., \& Lv, M. (2013). Dynamic Assessment in ESL Writing Classroom. ICETMS, 676-679.

[29] Moss, C. M., \& Brookhart, S. M. (2009). Advancing Formative Assessment in Every Classroom, a guide for instructional leaders. USA: ASCD publications.

[30] Murphy, R. (2011). Dynamic Assessment, Intelligence and Measurement. West Sussex: John Wiley \& Sons Ltd.

[31] Nicol, D. J., \& Macfarlane-Dick, D. (2006, april). Formative assessment and self-regulated learning: a model and seven principles of good feedback practice. Studies in Higher Education, 31, 199-218. 
[32] Poehner, M. E. (2008). A Vygotskian Approach to Understanding and Promoting L2 Development. Pennsylvania: Springer.

[33] Poehner, M. E., \& Lantolf, J. P. (2005). Dynamic Assessment in the Language Classroom. Language Teaching Research, 233-265.

[34] Ramaprasad, A. (1983). On the definition of feedback. Behavioral Sciences, 28 (1), 4-13.

[35] Richards, J. C., \& Renandya, W. A. (2002). Methodology in Language Teaching. New York: Cambridge University Press.

[36] Shrestha, P., \& Coffin, C. (2012). Dynamic assessment, tutor mediation and academic writing development. Assessing Writing, 55-70.

[37] Sperling, M. (1996). Revisiting the Writing-Speaking Connection: Challenges for Research on Writing and Writing Instruction. Review of Educational Research, Vol. 66, No.1, 53-86.

[38] Stern, L. A., \& Solomon, A. (22-41). Effective faculty feedback: The road less traveled. Assessing Writing, 11 (1), 2006.

[39] Swales, J. M. (1990). Genre Analysis. English in Academic and Research Setting. Cambridge: Cambridge University Press.

[40] Taras, M. (2005). Assessment - Summative and Formative Some Theoretical Reflections. British Journal of Educational Studies, 466-478.

[41] Ur, P. (2009). A Course in Language Teaching. Cambridge: Cambridge University Press.

[42] Walker, M. (2009). An investigation into written comments on assignments: Do students find them usable? Assessment and Evaluation in Higher Education, 34 (1), 67-78.

[43] Weaver, M. R. (2006). Do students value feedback? Student perceptions of tutors' written responses. Assessment and Evaluation in Higher Education, 31 (3), 379-394.

[44] Wiliam, D. (2011). What is Assessment for Learning. Studies in Educational Evaluation, 3-14.

[45] Xiaoxiao, L., \& Yan, L. (2010). A Case Study of Dynamic Assessment in EFL Process Writing. Chinese Journal of Applied Linguistis, 24-40.

[46] Yan, G. (2005). A Process Genre Model for Teaching Writing. English Teaching Forum, Vol. 43, No. 3, 18-26. 